lites. Oral administration of nicotinic acid in small doses produced flushing, "burning," and "itching" of the skin but oral nicotinamide was well tolerated, resulting in improvement of the photosensitive skin rash.

\section{REFERENCES AND NOTES}

1. Asatoor, A. M., Craske, J., London, D. R., and Milne, M. D.: Indole production in Hartnup disease. Lancet, $i: 126$ (1963).

2. Baron, D. N., Dent, C. E., Harris, H., Hart, E. W., and Jepson, J. B.: Hereditary pellagra-like skin rash with temporary cerebellar ataxia, constant renal aminoaciduria, and other bizarre biochemical features. Lancet, ii: 421 (1956).

3. Carpenter, K. J., and Kodicek, E.: The fluorimetric estimation of $N^{\prime}$-methylnicotinamide and its differentiation from coenzyme I. Biochemistry, 46: 421 (1950).

4. Chen, J., and Matchett, W. H.: Occurrence of $\mathrm{N}$-formylkynurenine in extracts of Neurospora crassa: Evidence for the activity of tryptophan pyrrolase. J. Bacteriol., 118: 837 (1974).

5. Coppini, D., Benassi, C. A., and Montorsi, M.: Quantitative determination of tryptophan metabolites (via kynurenine) in biologic fluids. Clin. Chem., 5: 391 (1959).

6. Denckla, W. D., and Dewey, K.: The determination of tryptophan in plasma, liver, and urine. J. Lab. Clin. Med., 69: 160 (1967).

7. Henry, R. J., and Chiamori, N.: On the direct Nesslerization of ammonia formed by urease treatment of blood, serum and urines. Amer. J. Clin. Pathol., 29: 277 (1958).

8. Knox, W. E., and Mehler, A. H.: The conversion of tryptophan to kynurenine in liver. I. The coupled tryptophan peroxidase-oxidase system forming formylkynurenine. J. Biol. Chem., 187: 419 (1950).

9. Milne, M. D., Crawford, M. A., Girão, C. B., and Loughridge, L. W.: The metabolic disorder in Hartnup disease. Quart. J. Med., 29: 407 (1960).

10. Moore, S., Spackman, D. H., and Stein, W. H.: Chromatography of amino acids on sulfonated polystyrene resins: An improved system. Anal. Chem., 30: 1185 (1958).

Copyright (c) 1976 International Pediatric Research Foundation, Inc.
11. Paul, J.: In: Cell and Tissue Culture (The Williams \& Wilkins Co., Inc., Baltimore, 1961).

12. Scriver, C. R.: Hartnup disease, a genetic modification of intestinal and renal transport of certain neutral alpha-amino acids. New Engl. J. Med., 273: 530 (1965).

13. Sharlit, H.: A method for the quantitative estimation of indoxyl compounds in urine. J. Biol. Chem., 99: 537 (1933)

14. Skoog, W. A., and Beck, W. S.: Studies on fibrinogen, dextran and phytohemagglutinin methods of isolating leukocytes. Blood, 11:436 (1956).

15. Smith, I.: In: Chromatographic and Electrophoretic Techniques, Vol. 1, p. 96 (Interscience Publishers, Inc.. New York, 1960).

16. Tada, K., Ito, H., Wada, Y., and Arkawa, T.: Congenital tryptophanuria with dwarfism. Tokohu J. Exp. Med., 80: 118 (1963).

17. Udenfriend, S., Titus, E., and Weissbach, H.: The identification of 5-hydroxy-3indoleacetic acid in normal urine and method for its assay. J. Biol. Chem., 216: 499 (1955).

18. Weissbach, H., King, W., Sjoerdsma, A., and Udenfriend, S.: Formation of indole-3-acetic acid and tryptamine in animals: A method for estimation of indole-3-acetic acid in tissues. J. Biol. Chem., 234: 81 (1959).

19. Wong, P. W. K., Lambert, A. M., Pillai, P. M. and Jones, P. M.: Observations on nicotinic acid therapy in Hartnup disease. Arch. Dis. Childhood, 42: 642 (1967).

20. Wong, P. W. K., and Pillai, P. M : Clinical and biochemical observations in two cases of Hartnup disease. Arch. Dis. Childhood, 4I: 383 (1966).

21. Yuwiler, A., Plotkin, S., Geller, E., and Ritvo, E. R .: A rapid accurate procedure for the determination of serotonin in whole human blood. Biochem. Med., 3: 426 (1970).

22. The authors would like to thank Kathryne Curley and Nancy Becker for their technical assistance.

23. This study was supported by a grant from the National Foundation-March of Dimes and by a grant from the Illinois Department of Mental Health.

24. Informed consent was obtained according to a protocol approved by the Research Committee.

25. Requests for reprints should be addressed to: P. W. K. Wong, M.D., Section of Genetics, Department of Pediatrics, Rush Medical School, 1753 W. Congress Parkway, Chicago, III. 60612 (USA).

26. Accepted for publication February 17, 1976.

\title{
Effect of Postweanling Pyridoxine Deficiency on Growth and Concentration of the Coenzyme Pyridoxal-5'-phosphate in Heart, Kidneys, Lungs, and Adrenals in Rats
}

\author{
HEMMIGE N. BHAGAVAN, ${ }^{34}$ JOHN M. KOOGLER, JR., AND DAVID B. COURSIN
}

Research Institute, St. Joseph Hospital, Lancaster, Pennsylvania, USA

\section{Extract}

Dietary pyridoxine deficiency induced in postweanling rats led to severe growth retardation and growth failure, with a sharp increase in the mortality rate after about 8 weeks on the diet. The absolute weights of heart, lungs, kidneys, and adrenals were all lower in the deficient animals than those of the controls. However, when the weights were expressed in terms of percentage of body weight, a 2 -fold increase was observed indicative of marked hypertrophy. The depletion of the coenzyme pyridoxal-5'-phosphate from these tissues was extensive (heart $48 \%$, lungs $85 \%$, and kidneys and adrenals $88 \%$ ). The extent of loss of the coenzyme from the tissues suggests possible functional changes.

\section{Speculation}

Functional disturbances may be expected as a consequence of the marked hypertrophy and the extensive depletion of the coenzyme pyridoxal-5'-phosphate from the heart, lungs, kidneys, and adrenals in postweanling pyridoxine-deficient rats. 
Pyridoxine (vitamin $\mathrm{B}_{6}$ ) plays an important role in cellular metabolism. Its involvement in the development and function of the central nervous system has also been well established (8). During the course of our studies on pyridoxine deficiency in experimental animals, we observed a differential depletion of the coenzyme pyridoxal-5'-phosphate (PLP) from brain, liver, and blood. The loss was found to be most rapid in blood and least in brain in postweanling pyridoxine-deficient animals $(2,5,16,17$, 24). In the case of the neonatal rats, however, at an age when the "blood-brain barrier" is not fully developed, the depletion from the brain was found to be more severe than in the young adult (2). Metabolic and functional disturbances as a direct consequence of the loss of PLP from brain have also been observed (2, 3, 8, 23-25). We now report data on the growth and the coenzyme status of heart, kidneys, lungs, and adrenals in weanling rats subjected to a dietary deficiency of pyridoxine.

\section{METHODS AND MATERIALS}

\section{ANIMALS AND DIETS}

Weanling Sprague-Dawley-derived male rats (31) were used in the study. They were divided into two groups of 12 animals each and housed in individual suspended stainless steel cages with wire bottoms in a temperature-regulated room $\left(74^{\circ} \mathrm{F}\right)$ with a $12-\mathrm{hr}$ light/dark cycle. One group received a pyridoxine-deficient diet, described earlier (3), and the other received the control diet (the deficient diet supplemented with $30 \mathrm{mg}$ pyridoxine $\mathrm{HCl} / \mathrm{kg}$ diet). The animals were fed ad libitum with free access to water.

\section{EXPERIMENTAL DESIGN}

The groups were fed the respective diets for 8 weeks by which time the animals not receiving the pyridoxine supplements were markedly deficient both by clinical and biochemical criteria as described previously (3). The animals were then killed by decapitation, and the tissues (heart, kidneys, lungs, and adrenals) rapidly excised and homogenized in ice-cold water using $5 \mathrm{ml} / \mathrm{g}$ except in the case of the adrenals (pooled), where $10 \mathrm{ml} / \mathrm{g}$ were used. Kidneys, lungs, and adrenals were homogenized using a PotterElvehjem-type homogenizer while heart was homogenized in an Omni-Mixer (32). The homegenates were frozen immediately in Dry Ice and stored frozen in a deep-freeze until analyzed for PLP (within 3 weeks).

\section{EXTRACTION AND ASSAY OF PLP}

The method for the extraction was a modification of the one described by Minard (18). All operations were carried out in cold and under subdued light unless otherwise indicated. The tissue homegenate $(1 \mathrm{ml})$ was treated with $1 \mathrm{ml} \mathrm{1.5 \% (w/v)} \mathrm{metaphos-}$ phoric acid (MPA) followed by $4 \mathrm{ml} 0.75 \%$ MPA, vortexed and held at $80^{\circ}$ for $15 \mathrm{~min}$ in a water bath. The precipitate was separated by centrifugation (about $25,000 \times g$ for $10 \mathrm{~min}$ ), washed once with $5 \mathrm{ml} 0.75 \% \mathrm{MPA}$, and the combined supernatants were brought to $\mathrm{pH} 5.5$ using $\mathrm{KOH}$ solution. The final volume of the extract was noted and diluted if necessary before using it in the assay.

PLP in the extracts was assayed by a modification (4) of the method described previously $(16,27)$, which is based upon the enzymatic decarboxylation of $\mathrm{L}-\left[1-{ }^{14} \mathrm{C}\right]$ tyrosine by tyrosine apodecarboxylase in the presence of PLP.

\section{RESULTS}

The body and tissue weights for both the groups are given in Table 1. The growth rate of the deficient rats was very poor and the body weights reached a plateau by the 6th week of the experimental period. The weights of heart, lungs, kidneys, and adrenals were also markedly lower in the deficient rats. However, the tissue weights expressed in terms of percentage of body weights were about 2 times the control values, thus indicating hypertrophy. One other possibility which cannot be ruled out without additional data is that these tissues were less affected by the deficiency.

The data on the PLP content of the tissues are given in Table 2. The depletion of PLP from the lungs, kidneys, and adrenals was severe (from about $85 \%$ to $88 \%$ ). Although the loss from the heart was much less in comparison (about $48 \%$ ), it was nevertheless highly significant.

\section{DISCUSSION}

The effects of pyridoxine deficiency such as marked reduction in growth, anorexia, acrodynia, and dermatitis noted in this study with postweanling rats have all been well documented in the literature, the only difference between the various reports being the length of time needed to produce clear-cut deficiency symptoms. Using the diet described by us (3), it is possible to induce rapidly the deficiency symptoms without the use of any dietary antagonists, which if used would confound the picture as far as the effects of a simple dietary deficiency are concerned. Under our experimental conditions, decreases in food intake and in the rate of growth are evident within the first few days after initiation of the dietary treatment in the postweanling rats. The mortality rate is very high after about 8 weeks on the diet. These young adults rarely show spontaneous convulsions, although $\gamma$-aminobutyric acid production in brain is reduced under similar conditions (28) because of decreased activity of the PLP-dependent enzyme, Lglutamate decarboxylase (22). On the other hand, neonatal rats subjected to pyridoxine deficiency (maternal) exhibit frequent episodes of spontaneous convulsions $(2,9,30)$.

Although there is a net decrease in the weights of all the four

Table 1. Body and tissue weights of pyridoxine-deficient and control rats

\begin{tabular}{|c|c|c|c|c|c|}
\hline Group & Body & Heart & Lungs $^{1}$ & $\begin{array}{l}\text { Kid- } \\
\text { neys }^{1}\end{array}$ & $\begin{array}{l}\text { Adre- } \\
\text { nals }^{1}\end{array}$ \\
\hline & \multicolumn{5}{|c|}{ Weights, $g \pm$ SEM } \\
\hline \multirow[t]{2}{*}{ Deficient $(16)^{2}$} & 93 & 0.522 & 0.774 & 1.418 & 0.0272 \\
\hline & \pm 2.7 & \pm 0.026 & ${ }_{ \pm 0} 0.036$ & ${ }_{ \pm 0} 0.103$ & \pm 0.0013 \\
\hline \multirow[t]{2}{*}{ Control $(16)^{2}$} & 353 & 1.062 & 1.448 & 2.830 & 0.0372 \\
\hline & \pm 12.5 & \pm 0.022 & \pm 0.042 & \pm 0.115 & \pm 0.0017 \\
\hline \multirow[t]{2}{*}{$P$} & $<0.01$ & $<0.01$ & $<0.01$ & $<0.01$ & $<0.01$ \\
\hline & \multicolumn{5}{|c|}{ Weights, expressed as \% body weight } \\
\hline Deficient & & 0.561 & 0.832 & 1.525 & 0.0297 \\
\hline Control & & 0.301 & 0.410 & 0.802 & 0.0153 \\
\hline
\end{tabular}

${ }^{1}$ Weights for the tissue pairs.

${ }^{2}$ Figures in parentheses indicate the number of animals.

Table 2. Pyridoxal-5'-phosphate (PLP) content of tissues in pyridoxine-deficient and control rats

\begin{tabular}{lrrrr}
\hline & \multicolumn{4}{c}{ PLP $(\mathrm{ng} / \mathrm{g}$ fresh weight \pm SEM) } \\
\cline { 2 - 5 } & \multicolumn{1}{c}{ Heart } & Lungs & Kidneys & Adrenals \\
\hline Deficient $(16)^{1}$ & 870.92 & 45.20 & 223.09 & 85.28 \\
& \pm 48.28 & \pm 2.38 & \pm 18.59 & \pm 24.29 \\
Control $(16)^{1}$ & $1,673.83$ & 303.25 & 1.926 .59 & 710.12 \\
& \pm 58.47 & \pm 24.53 & \pm 95.31 & \pm 151.18 \\
$P$ & $<0.01$ & $<0.01$ & $<0.01$ & $<0.01$ \\
Deficient as \% control & 52.03 & 14.91 & 11.58 & 12.00 \\
\hline
\end{tabular}

${ }^{1}$ Figures in parentheses indicate the number of animals. 
tissues studied in the deficient animals, the weights expressed in terms of their body weights are all higher when compared with those of the controls. This indicates marked hypertrophy of all the tissues, with the adrenals showing the maximum effect. Hypertrophy of the heart and kidneys has been noted before $(1,19,21)$. As for the adrenals, our data are in accord with those of Olsen and Martindale (19), Agnew (1), Combridge (7), and Eisenstein (14), although at variance with those of Delost and Terroine (11). This may be because of differences in the experimental design, especially in the diet composition and age of the animals, and hence in the degree of deficiency. The hypertrophies observed in the present study cannot be attributed to inanition in the deficient animals, since the data of Olsen and Martindale (19) clearly demonstrate no similar changes in hearts, kidneys, and adrenals in pair-fed control rats.

The data on the PLP content of the tissues in the deficient animals reveal a marked depletion in all four tissues, the kidneys, lungs, and adrenals being more severely affected than the heart. Data on the PLP content of heart and kidneys have been reported previously by Wachstein and Moore (29), but the values for the control tissues are much lower than ours. This may be because of methodologic differences, especially with respect to the extraction and assay of PLP.

The extensive depletion of PLP from the tissues as observed in the present study is quite likely to lead to functional disturbances. Our previous data, for instance, show an impairment in central nervous system function with a depletion of only about $50 \%$ from the brain (23-25). In the case of the kidneys, decreased renal concentrating ability (10), uremia (12), and increased lysosomal hydrolase activity (13) have been reported in the deficient animals. In humans, the existence of pyridoxine deficiency in uremic patients has recently been recognized (26). Cardiac lesions (21) have been described in pyridoxine-deficient animals, whereas in humans, pyridoxine deficiency has been shown to be associated with congestive heart failure (15). Adrenal dysfunction has been reported in the deficient animals (20). Although comparable data for humans are not available, it is quite likely that adrenal function would also be affected. No data exists in the literature on PLP content of lungs or on the pulmonary function in pyridoxine deficiency. However, the extent of depletion of PLP from the lungs as observed in the present study does suggest possible functional changes in this tissue also. The recent findings of increased excretion of tryptophan metabolites in childhood bronchial asthma and its reversal by therapeutic doses of pyridoxine (6) does indicate an important role for the vitamin in pulmonary function. Additional experimental data on the metabolic and functional changes in these tissues in pyridoxine deficiency will be of importance.

\section{SUMMARY}

Pyridoxine deficiency induced in postweanling rats led to $(l)$ severe growth retardation and growth failure; (2) marked hypertrophy of heart, lungs, kidneys, and adrenals as indicated by relatively higher tissue weights in relation to body weights; and (3) extensive depletion of the coenzyme pyridoxal-5-phosphate from these tissues.

\section{REFERENCES AND NOTES}

1. Agnew, L. R. C.: Cardiac, renal and hepatic hypertrophy in pyridoxine-deficient rats. Proc. Soc. Exp. Biol. Med. 90:452 (1955).

2. Bhagavan, H. N.: Unpublished data.
3. Bhagavan, H. N., and Coursin, D. B.: In vivo incorporation of $\mathrm{L}-\left[\mathrm{U}-{ }^{14} \mathrm{C}\right] \mathrm{lysine}$ and $\mathrm{L}-\left[\mathrm{U}-{ }^{14} \mathrm{C}\right]$ leucine into brain proteins in pyridoxine deficiency. Int. J. Vit. Nutr. Res., 41: 231 (1971).

4. Bhagavan, H. N., and Coursin, D. B.: Int. J. Vit. Nutr. Res. (In press.)

5. Bhagavan, H. N., and Stewart, C. N.: Tissue pyridoxal-5'-phosphate content and avoidance behavior in 4-deoxypyridoxine-treated rats. Int. J. Vit. Nutr. Res., 44: 357 (1974)

6. Collipp, P. J., Goldzier, S., III, Weiss, N., Soleymani, Y., and Snyder, R.: Pyridoxine treatment of childhood bronchial asthma. Ann. Allergy, 35: 93 (1975).

7. Combridge, C.: The effect of pyridoxine-deficiency on certain organs of the rat. Brit. J. Nutr., 10: 347 (1956)

8. Coursin, D. B.: Vitamin $B_{6}$ and brain function in animals and man. Ann. N. Y. Acad. Sci., 166: 7 (1969)

9. Dakshinamurti, K., and Stephens, M. C.: Pyridoxine deficiency in the neonatal rat. J. Neurochem., 16: 1515 (1969).

10. Davis, R. P., and Sloop, R. F., Jr.: Renal concentrating ability in pyridoxine deficiency. Proc. Soc. Exp. Biol. Med., 120: 418 (1965).

11. Delost, P., and Terroine, T.: Le surrenale au cours de la carence en pyridoxine chez le rat. J. Physiol., 54: 323 (1962).

12. DiPaolo, R. V., Caviness, V.S., Jr., and Kanfer, J. N.: Delayed maturation of the renal cortex in the vitamin $\mathrm{B}_{6}$-deficient newborn rat. Pediat. Res., 8: 546 (1974).

13. DiPaolo, R. V., Spielvogel, C., and Kanfer, J. N.: Increased lysosomal hydrolase activity in kidney and brain from vitamin $\mathrm{B}_{6}$-deficient developing rat. Pediat. Res., 9: 693 (1975)

14. Eisenstein, A, B.: Relationshin of vitamin $\mathrm{B}_{6}$ to adrenocortical function in the rat. Proc. Soc. Exp. Biol. Med., 100: 111 (1959).

15. Levy, H. A., Wohl, M. G., and Szutka, A.: Pyridoxine deficiency in congestive heart failure. Proc. Soc. Exp. Biol. Med., 101: 617 (1959).

16. Maruyama, H., and Coursin. D. B.: Enzymic assay of pyridoxal phosphate using tyrosine apodecarboxylase and tyrosine-1- ${ }^{14} \mathrm{C}$. Anal. Biochem., 26: 420 (1968).

17. Maruyama, H., and Coursin, D. B.: Enzymatic assay of PALP using tyrosine apodecarboxylase and tyrosine- $1-{ }^{14} \mathrm{C}$. In: K. Yamada, N. Katunuma, and H. Wada: International Symposium on Pyridoxal Enzymes, p. 235 (Maruzen Co., Tokyo, 1968)

18. Minard, F. N.: Relationships among pyridoxal phosphate, vitamin $B_{6}$ deficiency, and convulsions induced by 1,1-dimethylhydrazine. J. Neurochem.. 14:681 (1967).

19. Olsen, N. S., and Martindale, W. E.: Studies on chronic vitamin $B_{6}$ deficiency in the rat. II. Changes in tissues metabolism. J. Nutr., 53: 329 (1954)

20. Ratsimamanga, A. R., Boisselot-Lefebvres, J., and Nigeon-Dureuil, M.: Survie de jeunes rats, partiellement ou totalement prives de vitamines B, soumis au test surrenalien de protection contre le froid et l'inanition. J. Physiol., 52: 206 (1960).

21. Seronde, J., Jr.: Cardiac lesions and related findings in young vitamin $B_{6}$-deficient rats. J. Nutr., 72: 53 (1960).

22. Stephens, M., Havlicek, V., and Dakshinamurti, K.: Pyridoxine deficiency and the development of the central nervous system in the rat. J. Neurochem., 18: 2407 (1971).

23. Stewart, C. N., Bhagavan, H. N., and Coursin, D. B.: Some behavioral consequences of pyridoxine deficiency in rats. In: K. Yamada, N. Katunuma, and H. Wada: International Symposium on Pyridoxal Enzymes, p. 181 (Maruzen Co., Tokyo, 1968).

24. Stewart, C. N., Coursin, D. B., and Bhagavan, H. N.: Cortical-evoked responses in pyridoxine-deficient rats. J. Nutr., 103: 462 (1973)

25. Stewart, C. N., Coursin, D. B., and Bhagavan, H. N.: Avoidance behavior in vitamin $B_{6}$-deficient rats. J. Nutr., 105: 1363 (1975).

26. Stone, W. J., Warnock, L. G., and Wagner, C.: Vitamin $B_{6}$ deficiency in uremia. Amer. J. Clin. Nutr., 28: 950 (1975).

27. Sundaresan, P. R., and Coursin, D. B.: Microassay of pyridoxal phosphate using L-tyrosine-1- ${ }^{14} \mathrm{C}$ and tyrosine apodecarboxylase. Methods Enzymol., 18 A: 509 (1970).

28. Tews, J. K.: Pyridoxine deficiency and brain amino acids. Ann. N. Y. Acad. Sci., 166: 74 (1969)

29. Wachstein, M., and Moore, C.: Pyridoxal phosphate $\left(\mathrm{B}_{6}\right.$-al- $\left.\mathrm{PO}_{4}\right)$ levels in organs, leukocytes and blood of rats with developing vit. $B_{6}$ deficiency. Proc. Soc. Exp. Biol. Med., 97: 905 (1958).

30. Wiss, O., and Weber, F.: Biochemical pathology of vitamin $B_{6}$ deficiency. Vit Horm., 22: 495 (1964)

31. CD strain, Charles River Breeding Laboratories, Wilmington, Mass.

32. Sorvall, Newton, Conn.

33. This investigation was supported by National Institutes of Health Grants NS 05789, NS 07361, and GRS RR 05657, United States Public Health Service.

34. Requests for reprints should be addressed to: H. N. Bhagavan, Ph. D., Research Institute, St. Joseph Hospital, Lancaster, Pa. 17604 (USA).

35. Accepted for publication February 17, 1976. 